\title{
THE ROLE OF LIBRARIES IN RESEARCH INSTITUTIONS IN SUPPORTING DATA DISEMINATION AND SCIENTIFIC WORKS
}

\author{
Tupan* and Retno Asihanti Setiorini \\ Centre for Data and Scientific Documentation, LIPI, Jakarta Selatan
}

*Correspondence: tupan712190@gmail.com

\begin{abstract}
Scientific data and papers generated from research activities are assets that need to be preserved so it could be reused in the future. To increase the use of scientific data and papers, it is necessary to disseminate scientific data and papers. This narrative review research was conducted to determine the role of libraries in disseminating data and scientific papers. This research was conducted to answer the following questions. First, what is the role of libraries in supporting the process of data dissemination and scientific works? Second, what support does the library provide in supporting data dissemination and scientific works? Thirdly, what resources are available in the library to assist in the process of data dissemination and scientific work? The narrative review method is carried out by analyzing related scientific articles. The search was carried out using online journal references indexed in the Scopus database. The results of the narrative review analysis show that libraries play a role in providing online data and information services, as well as encouraging open access to data and scientific papers. Libraries also play a role in providing access and dissemination of data and scientific works, and in conducting user education. The support provided by the library is to expand research data management, create research data management guidelines, create datasets to share research data, and improve information dissemination techniques through reference services, social networks, websites, mils, and OPAC. Resource support provided by libraries in supporting data dissemination and scientific work is establishing a data visualization clinic, providing a catalog of research data, developing data repositories, improving library services and resources related to data dissemination and scientific works to the public, and promoting institutional repositories.
\end{abstract}

\begin{abstract}
ABSTRAK
Data dan karya ilmiah yang dihasilkan dari kegiatan penelitian merupakan aset yang perlu dilestarikan agar dapat digunakan kembali di masa depan. Untuk meningkatkan penggunaan data dan karya ilmiah, data dan karya ilmiah tersebut perlu didiseminasikan. Penelitian narative review ini dilakukan untuk mengetahui peran perpustakaan dalam diseminasi data dan karya ilmiah. Penelitian ini dilakukan untuk menjawab pertanyaan sebagai berikut. Pertama, apa peran perpustakaan dalam mendukung proses diseminasi data dan karya ilmiah? Kedua, dukungan apa yang diberikan oleh perpustakaan dalam mendukung diseminasi data dan karya ilmiah? Yang ketiga sumber daya apa yang tersedia di perpustakaan untuk membantu dalam proses diseminasi data dan karya ilmiah? Metode narrative review dilakukan dengan melakukan anlisis terhadap artikel-artikel ilmiah terkait. Penelusuran dilakukan menggunakan referensi jurnal online yang terindeks pada database scopus. Hasil analisis narative review menunjukkan bahwa perpustakaan berperan dalam memberikan layanan data dan informasi online, serta mendorong akses terbuka data dan karya ilmiah. Perpustakaan juga berperan dalam menyediakan akses serta diseminasi data dan karya ilmiah, dan melakukan pendikan pemakai. Adapun dukungan yang diberikan perpustakaan adalah memperluas manajemen data penelitian, membuat pedoman pengelolaan data penelitian, membuat dataset untuk berbagi data penelitian, serta meningkatkan teknik diseminasi informasi melalui layanan referensi, jejaring sosial, situs web, mils dan OPAC. Dukungan sumber daya yang diberikan perpustakaan dalam mendukung diseminasi data dan karya ilmiah adalah membentuk klinik visualisasi data, menyediakan katalog data penelitian, mengembangan repositori data, meningkatkan layanan perpustakaan dan sumber daya yang berkaitan dengan diseminasi data dan karya ilmiah kepada masyarakat, serta mempromosikan repositori kelembagaan.
\end{abstract}

Keywords: Data management, Scientific papers, Dissemination, Libraries

\section{INTRODUCTION}

Library and librarian in research institution have a role in managing library collections, providing information services, and maintaining library information systems (Riyanto, Marlina, and Triasih 2019). In a research institution, these roles will help researchers to do research. However, through time, librarian roles in research institute transforming, not only managing literature nor information, but there are also needs for managing scientific data. The so-called big data which have feature of volume, variety, 
and velocity generates the needs of management data (Pinfield, Cox, and Smith 2014). Researchers and funder are also having awareness of the importance of sharing data, despite all the challenges. All of this requires effective research data management. Library and librarians are able to take part in this consider that they already have taken part in managing literature, including scientific papers.

Scientific data and papers generated from the research and study process are assets of science and technology. They needed to be disseminated to the public in order to increase the nation's competitiveness and the development of science and technology. Scientific data and papers management will also improve the quality of research. In addition, the scientific data and papers produced by research institutions are a reflection of the quality and visibility of the research institutions. Data and scientific papers from research results produced by institutional members are one of the indicators of an institution's success in ranking research institutions (Ulum, 2011).

Dissemination is an activity to deliver information to groups or individuals in order to make that groups or individuals motivated to receive and utilize the information (Syarianah 2016). The term commonly used in the world of research is sharing information/ knowledge. In relation to scientific data and papers, dissemination can be defined as the activity of sharing data and scientific work for reuse for the improvement and advancement of research quality. In other words, dissemination does not stop at sharing, but beyond that, it triggers the recipient of information/knowledge to make use of it.

As scientific data and papers manager in research institutes, libraries in research institutions take a role and contribute to disseminating scientific data and papers to the public. Libraries contribute to the process of how the data is recorded, stored, and maintained, and shared for future use through the process of dissemination. In addition, libraries have a role in providing research data services to researchers related to data management, information retrieval, citation data, and technical services related to institutional repository management (Tenopir, Birch, and Allard 2012).

Charbonneau (2013) said that the library must take its role in supporting the management of scientific data and papers. Currently, data service activities and scientific works searches are services that can be further developed as a part of library services. Researchers and the public could take advantage of data management services, data retrieval, data repackaging, and so on. Chiware and Mathe (2016) state that the need for data services and scientific works is a necessity in the current era of globalization. This means that researchers can collaborate with other researchers in other parts of the world. Data management services and scientific papers are kept and preserved in an institutional repository that in line with the concept of the scientific communication cycle. The existence of institutional repositories can be used as an opportunity for research data services which are all in digital form or better known as the digital ecosystem.

Previous research related to data and scientific works dissemination are Syarianah (2016) and Rahayu (2016). Syarianah (2016) conducted a study on monitoring the dissemination of research results at the Brackish Water Research and Development Center 2010-2015. Dissemination of the research and development carried out by the Maros Brackish Water Aquaculture Research and Development Center using the dissemination system. Within a period of six years, from 2010 to 2015 , dissemination activities were carried out 24 times, in 8 provinces, covering 15 districts and cities. Science and technology materials that are most frequently disseminated are seaweed cultivation technology, shrimp cultivation technology, probiotic application technology, fish/ environmental health technology, shrimp polyculture technology, red tilapia, milkfish and seaweed, and crab cultivation technology. From this dissemination, 
it is expected that all pond farmers or cultivators will be able to develop and increase productivity and profits in their cultivation business.

Rahayu (2016) conducted a study on the role of librarians in supporting knowledge management repositories at the Ministry of Marine Affairs and Fisheries. In this research, it is said that through the application of knowledge management in libraries, a scientific communication process will continue to develop because the essence of knowledge management is sharing knowledge. In this case, the library could take the role of collecting, processing, storing, and disseminating knowledge that has been produced by researchers, extension agents, and policy makers. In library activities, knowledge management is the daily activities. Organizing activities are always followed by storage. If activities are carried out at the organizational level, knowledge is stored in a knowledge repository or a server that can be accessed collectively. The existence of this knowledge repository and the availability of data in it are prerequisites for the exchange and incorporation of knowledge that allows the creation of new knowledge.

Previous studies have stated that the role of libraries in the management of scientific data and works. Libraries are expected to take a part in the role of data management and that includes data sharing. However, the question that arises is whether libraries in research institutions did have taken a role in disseminating data and scientific works? Based on these problems, a narrative review of the role of research institutions libraries in supporting the dissemination of data and scientific papers was conducted. The study aims to determine (1) the role of libraries in research institutions in disseminating data and scientific works; (2) support provided by libraries in research institutions in the dissemination of data and scientific works; and (3) resources provided by libraries in disseminating scientific data and papers.

\section{METHOD}

The research was conducted using the narrative review method. The narrative review method is related to the systematic review method, used for looking for approaches to identification, quality assessment, and study synthesis (Best, Manktelow, and Taylor 2014). The results of systematic reviews can be statistical (quantitative) or narrative (qualitative). Because this research was conducted to find answers qualitatively, the method used was a narrative review. The narrative review method in this research is carried out by searching scientific works related to the role of libraries in supporting scientific data and papers dissemination to answer the following questions: (1) what is the role of libraries in supporting the process of scientific data and papers dissemination? (2) what support does the library provide in supporting the scientific data and papers dissemination process? (3) What resources are available in the library to assist in the process of disseminating scientific data and papers?

Literature searches were carried out from May to June 2020 using online journal references indexed in the Scopus and Google Scholar databases. The search was conducted to find relevant material using key phrases: (information AND dissemination) OR TITLE (research AND data AND management) AND TITLE (library). From the search conducted, obtained 25 scientific articles and books. The results are then selected based on their suitability with the research topic. Based on the selection, obtained 16 articles. The selected works are then analyzed and compiled according to the questions asked.

\section{RESULTS AND DISCUSSION}

\subsection{RESULTS}


From the search results through Google Scholar and Scopus, 16 articles were obtained which were suitable for the topic. After the analysis process of the articles, the topics of articles then divided into three main themes, in line with the question research, namely: the role of libraries in scientific data and papers dissemination; support provided by libraries in disseminating scientific data and papers; resources provided by the library in disseminating scientific data and papers. The three themes of the narrative review results can be seen in Tables 1, 2, and 3 below.

Table 1. The Role of Libraries in Scientific Data and Papers Dissemination

\begin{tabular}{|c|c|}
\hline Authors, titles and sources & Libraries' roles \\
\hline $\begin{array}{l}\text { Kevin B. Read; Jessica Koos, AHIP; Rebekah S. } \\
\text { Miller; Cathryn F. Miller; Gesina A. Phillips; Laurel } \\
\text { Scheinfeld; Alisa Surkis. (2019). A Model for } \\
\text { Initiating Research Data Management Services at } \\
\text { Academic Libraries. Journal of the Medical Library } \\
\text { Association } 107 \text { (3) July } 2019\end{array}$ & $\begin{array}{l}\text { Developing research data services } \\
\text { Providing research data management training }\end{array}$ \\
\hline $\begin{array}{l}\text { Shelly, M., \& Jackson, M. (2018). Research Data } \\
\text { Management Compliance: Is There a Bigger Role for } \\
\text { University Libraries? Journal of The Australian } \\
\text { Library And Information Association Vol. 67, No. 4, } \\
\text { 394-410 }\end{array}$ & $\begin{array}{l}\text { Managing research data services } \\
\text { Developing research data management policies } \\
\text { Developing research data access policies } \\
\text { Encouraging open access to research data } \\
\text { Providing access to research data } \\
\text { Providing advice to researchers in creating metadata } \\
\text { and saving data to the repository }\end{array}$ \\
\hline $\begin{array}{l}\text { Yoon, A.a, Schultz, T.b. (2017). Research Data } \\
\text { Management Services in Academic Libraries in The } \\
\text { US: A Content Analysis Of Libraries' Website. } \\
\text { College and Research Libraries Volume 78, Issue 7, } \\
\text { November 2017, Pages 920-933 }\end{array}$ & $\begin{array}{l}\text { Providing research data services } \\
\text { Providing online information } \\
\text { Providing users' education } \\
\text { Providing networking services }\end{array}$ \\
\hline $\begin{array}{l}\text { Chiware E \& Mathe Z (2015). Academic Libraries' } \\
\text { Role in Research Data Management Services: a } \\
\text { South African Perspective. South African Journal of } \\
\text { Libraries and Information Science. 81(2), 2-10. }\end{array}$ & $\begin{array}{l}\text { Developing and integrating research data services } \\
\text { through repositories } \\
\text { Educating on research data collection } \\
\text { Disseminating research results through open access } \\
\text { Educating research data curation }\end{array}$ \\
\hline $\begin{array}{l}\text { Tenopir, C., Sandusky, R.J., Allard, S., Birch, B. } \\
\text { 2014. Research Data Management Services In } \\
\text { Academic Research Libraries And Perceptions Of } \\
\text { Librarians. Library and Information Science } \\
\text { Research 36(2), pp. 84-90 }\end{array}$ & $\begin{array}{l}\text { Providing research data services } \\
\text { Preparing and preserving research data in a data } \\
\text { repository }\end{array}$ \\
\hline $\begin{array}{l}\text { Corrall, Sheila (2012) Roles and responsibilities: } \\
\text { Libraries, librarians and data. In: Managing } \\
\text { research data. Facet Publishing, London, } 105-133 . \\
\text { ISBN } 9781856047562\end{array}$ & $\begin{array}{l}\text { Developing and managing access to data collections } \\
\text { Developing the principles of open science } \\
\text { Developing national and institutional data management } \\
\text { policies } \\
\text { Developing data curation capacity } \\
\text { Providing power management consultations }\end{array}$ \\
\hline $\begin{array}{l}\text { Tenopir, C, Birch, B., Allard, S. (2012). Academic } \\
\text { libraries and research data services: current practices } \\
\text { and plan for the future (an ACRL White Paper). } \\
\text { Association of College \& Research Libraries. } \\
\text { Chicago: Illinoi }\end{array}$ & $\begin{array}{l}\text { Providing data services } \\
\text { Data management } \\
\text { Data searching } \\
\text { Institutional repositories management }\end{array}$ \\
\hline
\end{tabular}

Table 2. The Supports Given by The Libraries in the Dissemination of Scientific data and Papers

\begin{tabular}{|l|l}
\hline Authors, titles and sources & Libraries' supports \\
\hline
\end{tabular}




\begin{tabular}{|c|c|}
\hline $\begin{array}{l}\text { Payal, Shipra Awasthi and Manorama Tripathi } \\
\text { (2019). A Selective Review of Literature on Research } \\
\text { Data Management in Academic Libraries. Journal of } \\
\text { Library \& Information Technology, Vol. 39, No. 6, } \\
\text { Nov 2019, pp. 338-345, DOI : } \\
\text { 10.14429/djlit.39.6.14451 }\end{array}$ & $\begin{array}{l}\text { Expanding data management } \\
\text { Creating data management guidelines for researchers } \\
\text { Assisting researchers in creating datasets for data } \\
\text { sharing }\end{array}$ \\
\hline $\begin{array}{l}\text { Shonhe, Liah, "A Literature Review of Information } \\
\text { Dissemination Techniques in the } 21 \text { st Century Era" } \\
\text { (2017). Library Philosophy and Practice (e-journal). } \\
\text { 1731. } \\
\text { https://digitalcommons.unl.edu/libphilprac/1731 }\end{array}$ & $\begin{array}{l}\text { Improving information dissemination techniques } \\
\text { through reference services, social networks, mailing } \\
\text { list, websites and OPAC }\end{array}$ \\
\hline $\begin{array}{llll}\text { Charbonneau. D.H. (2013). Strategies for Data } \\
\text { Management } & \text { Engagement. } & \text { Medical } & \text { Reference } \\
\text { Services Quarterly. 32(3): 365-374. } & \end{array}$ & $\begin{array}{l}\text { Pioneers in the development of systems and process of } \\
\text { information delivery } \\
\text { Proactive and responsive in research data management } \\
\text { As an advisor, trainer, and supporter for researchers in } \\
\text { managing research data } \\
\text { As a creator, collector, manager and user of data }\end{array}$ \\
\hline $\begin{array}{l}\text { Rosie Hanneke, MLS, AHIP; Jeanne M. Link, MLS, } \\
\text { MS. (2019). The Complex Nature of Research } \\
\text { Dissemination Practices Among Public Health } \\
\text { Faculty Researchers }\end{array}$ & $\begin{array}{l}\text { Improving library services and resources related to the } \\
\text { dissemination of research results } \\
\text { Supporting data visualization to disseminate research } \\
\text { results to the public } \\
\text { Promoting institutional repositories }\end{array}$ \\
\hline $\begin{array}{l}\text { Anna Clementsa, Valerie McCutcheonb (2014). } \\
\text { Research Data Meets Research Information } \\
\text { Management: Two Case Studies Using (A) Pure } \\
\text { CERIF-CRIS and (B) Eprints Repository Platform } \\
\text { with CERIF Extensions. Procedia Computer Science } \\
33 \text { (2014) } 199 \text { - 206 }\end{array}$ & $\begin{array}{l}\text { Kebijakan manajemen data terbuka } \\
\text { Open data management policy } \\
\text { Infrastructure supports for developing d } \\
\text { management }\end{array}$ \\
\hline
\end{tabular}

Table 3. The Resources Provided by The Libraries in The Dissemination of Scientific Data and Papers

\begin{tabular}{|c|c|}
\hline Authors, titles and sources & Resources provided by the libraries \\
\hline $\begin{array}{l}\text { Rosie Hanneke, MLS, AHIP; Jeanne M. Link, MLS, } \\
\text { MS. (2019). The Complex Nature of Research } \\
\text { Dissemination Practices Among Public Health } \\
\text { Faculty Researchers }\end{array}$ & $\begin{array}{l}\text { Improving library services and resources related to the } \\
\text { dissemination of research results } \\
\text { Supporting data visualization to disseminate research } \\
\text { results to the public } \\
\text { Promoting institutional repositories }\end{array}$ \\
\hline $\begin{array}{l}\text { Fred Willie Zametkin LaPolla; Denis Rubin (2018), } \\
\text { The "Data Visualization Clinic": a library-led } \\
\text { critique workshop for data visualization. Journal of } \\
\text { the Medical Library Association } 106 \text { (4) October } \\
2018\end{array}$ & $\begin{array}{l}\text { Developing data visualization clinics } \\
\text { Building networks among researchers }\end{array}$ \\
\hline $\begin{array}{l}\text { Andrew M. Cox, Mary Anne Kennan, Liz Lyon, } \\
\text { Stephen Pinfield. (2017). Developments in Research } \\
\text { Data Management in Academic Libraries: Towards } \\
\text { an Understanding of Research Data Service } \\
\text { Maturity. Journal of the Association for Information } \\
\text { Science and Technology Volume 68, Issue 9, } \\
\text { September 2017, Pages 2182-2200 }\end{array}$ & $\begin{array}{l}\text { Providing advocacy for research data management } \\
\text { policies } \\
\text { Curation of research data training } \\
\text { Provisioning of research data catalogs }\end{array}$ \\
\hline $\begin{array}{l}\text { Alexandra Naum (2014). Research Data Storage and } \\
\text { Management: Library Staff Participation In }\end{array}$ & $\begin{array}{l}\text { Librarians be parts of research activities } \\
\text { Development of data repositories }\end{array}$ \\
\hline
\end{tabular}




\begin{tabular}{|l|l|}
\hline Showcasing Research Data At The University Of & Metadata storage \\
Adelaide. The Australian Library Journal, 2014 Vol. & \\
63, No. 1, 35-44, & \\
\hline Karen Antell, Jody Bales Foote, Jaymie Turner, and & Librarians' competency in data management \\
Brian Shults. (2014). Dealing with Data: Science & Developing data repositories \\
Librarians' Participation in Data Management at & \\
Association of Research Libraries Institutions. & \\
College \& Research Libraries 75(4) & \\
\hline
\end{tabular}

\subsection{DISCUSSION}

\subsubsection{The Role of Libraries in The Dissemination of Scientific Data and Papers}

Based on the articles, (Read et al. 2019) conducted research on the development of research data management service models in university libraries. The results showed that libraries in universities developed an online research data service model for researchers and librarians. This study concludes that librarians in universities could play a role and collaborate with researchers in developing research data management and play an active role in managing research data for the purpose of dissemination data and scientific papers.

Shelly and Jackson (2018) conducted a study on the main role of libraries in managing research data services. The results of the study found that the library is active in providing suggestions to researchers about the importance of managing research data, especially in providing support for creating metadata and storing data in repositories. This role is performed by a metadata librarian. To support these services, training on data management and storage was conducted for researchers with the aim that the resulting data could be used and disseminated for further research. The results also show that libraries can take a bigger role in managing research data.

In line with the previous research, Yoon and Schultz (2017) said that the readiness of libraries in managing research data has been carried out by collecting and managing research data and providing support to researchers in order to get researchers to store their data in a repository. To improve librarian skills in managing research data, training is held for library staff. Libraries are viewed as positive and characterized as neutral bodies that can provide services to both researchers and library staff. Academic libraries seek to find a foothold among their institutional counterparts in research data management forums to identify roles and responsibilities. Future research may include further understanding of how positive perceptions of academic libraries can be utilized to gain trust to support research data management. Other areas requiring further investigation include identifying optimal conditions for providing technical services and evaluating strategies for enhancing library staff/ librarians in the management of research data and scientific work for dissemination purposes.

Chiware and Mathe (2016) state that the role of libraries is to develop and integrate research data services through repositories, data collection, curate research, data and scientific papers to researchers. In addition, libraries also play a role in disseminating data and scientific works in the form of open access. The same opinion was also expresesed by other researchers (Tenopir, Birch, and Allard 2012; Tenopir et al. 2014) that libraries play an important role in supporting research data services ranging from planning, collecting, to preserving data in repositories for dissemination purposes. Libraries play a role in developing and managing access to data collections, developing principles of open sciences, making national and institutional data management policies, and curating data (Corrall 2018). 
From all the articles above, it can be concluded that data management services and scientific works are needed in research institutions; training in the management of data and scientific papers needs to carried out for researchers and/or librarians in relation to encouraging the dissemination of scientific data and papers, and libraries and librarians can play a role in research data management. In terms of managing data and scientific papers, the services that can be provided by libraries are: (1) repository, (2) data collection education, (3) data curation and scientific papers; (4) dissemination of data and scientific papers; (5) planning, collecting, preserving research data for dissemination; (6) develop and manage data collection access; (7) developing open science principles; (8) formulating data management policies (national and institutional); (9) provides support for metadata creation and data storage to repositories.

\subsubsection{Supports Given by The Libraries in The Dissemination of Scientific Data and Papers} Payal, Awasthi, and Tripathi (2019) revealed that the support provided by libraries in data dissemination and scientific work is to expand data management and scientific work, create data management guidelines for researchers, and help researchers in creating data sets, and preparing infrastructure for dissemination purposes. The existence of data management and policy support, as well as infrastructure support provided by the library, will make it easier for these data and works to be traced if needed. Shonhe (2017) said the support provided by libraries is to improve information dissemination techniques through reference services, social networks, mailing lists, and OPAC websites.

Charbonneau (2013) stated that the support provided by libraries in the dissemination of scientific data and papers is to be a pioneer in development systems, information dissemination processes, and also being proactive and responsive in managing research data. Libraries also function as advisors, trainers, and support researchers in managing research data, namely as creators, collectors, managers, and users of data and scientific papers. Meanwhile, Hanneke and Link (2019) said the support provided by libraries is to improve library services and resources related to dissemination of research results, support data visualization to disseminate research results to the public, and promote institutional repositories.

From these articles, it is known that library support for data dissemination and scientific works is related to several things, namely: (1) data management and scientific work; (2) dissemination process; (3) service improvement. It is stated that libraries play a role in expanding management of scientific data and papers, making data management guidelines for researchers and assisting researchers in creating data sets, as well as being proactive and responsive in managing research data for creators, collectors, managers, and users of data and scientific papers. Regarding data dissemination and scientific works, libraries have the role of preparing infrastructure for dissemination purposes; improve techniques for disseminating information through reference services, social networks, mailing list websites, and OPAC; a pioneer in systems development, information dissemination processes; support data visualization to disseminate research results to the public. In relation to services, library support for data dissemination and scientific works to improve library services and resources related to dissemination of research results and promote institutional repositories.

\subsubsection{Resources Provided by Libraries in The Dissemination of Scientific Data and Papers}

Hanneke and Link (2019) state that the resources provided by libraries in data dissemination and scientific works are library services and resources related to the dissemination of research. The resource (librarian) in charge of creates data visualizations for the purposes of disseminating research to the public and promoting institutional repositories. Lapolla and Rubin (2018) stated that library resources are data visualization clinics and networks building between researchers to improve the dissemination of data and scientific papers. 
Library resources provide research data management policy advocacy, research data curation training, and provide data catalogs and scientific papers for dissemination purposes. However, Naum (2014) said librarians are members of research activities. The library resources also support developing data repositories as well as metadata storage. Library resources increase competence in data management and develop data repositories to improve data dissemination (Antell et al. 2014).

From the articles above, it is known that the largest resource related to data dissemination and scientific works is the human resource of libraries, librarians. Dissemination of scientific data and papers are related to librarian competencies: data visualization, building research networks, providing research data management, policy advocacy, curating research data, cataloging data and scientific papers, being a member of the research team, and developing repositories and metadata.

\section{CONCLUSION}

This research found 16 scientific articles related to the theme of dissemination of scientific data and works/ papers. Based on the analysis, it is known that there are three main themes discussed, (1) the role of libraries in the dissemination of scientific data and papers; (2) support provided by libraries in disseminating of scientific data and papers; (3) resources provided by the library in disseminating scientific data and papers. The role of libraries in data dissemination and scientific work is to provide data services and scientific works, encourage open access to data and scientific works, provide access and dissemination of data and scientific works, and conduct user training. Meanwhile, library support for data dissemination and scientific works related to several matters, namely: (1) management of scientific data and papers; (2) dissemination process; (3) service improvement. The support provided by the library in data dissemination and scientific papers is to expand research data management, create guidelines for research data management, create datasets to share research data, and improve information dissemination techniques through reference services, social networks, websites, mailing lists, and OPAC. Resources provided by the library in disseminating data and scientific works related to human resource competencies, namely librarians. The competence of librarians who plays a role in data dissemination and scientific work is to create data visualization clinics, provide research data catalogs, develop data repositories, improve library services and resources related to data dissemination and scientific works to the public, and promote institutional repositories. The recommendation based on this research is to develop the compentencies of librarians in research institutions in order to give opportunities for libraries' play role in the dissemination of scientific data dan papers.

\section{BIBLIOGRAPHY}

Antell, Karen, Jody Bales Foote, Jaymie Turner, and Brian Shults. 2014. "Dealing with Data: Science Librarians' Participation in Data Management at Association of Research Libraries Institutions." College and Research Libraries 75 (4): 557-74. https://doi.org/10.5860/crl.75.4.557.

Best, Paul, Roger Manktelow, and Brian Taylor. 2014. "Online Communication, Social Media and Adolescent Wellbeing: A Systematic Narrative Review." Children and Youth Services Review 41: 27-36. https://doi.org/10.1016/j.childyouth.2014.03.001.

Charbonneau, Deborah H. 2013. "Strategies for Data Management Engagement." Medical Reference Services Quarterly 32 (3): 365-74. https://doi.org/10.1080/02763869.2013.807089.

Chiware, Elisha R.T., and Zanele Mathe. 2016. “Academic Libraries' Role in Research Data Management Services: A South African Perspective." South African Journal of Libraries and Information Science 81 (2): 1-10. https://doi.org/10.7553/81-2-1563.

Corrall, Sheila. 2018. "Roles and Responsibilities: Libraries, Librarians and Data." Managing Research Data, no. January 2012: 105-34. https://doi.org/10.29085/9781856048910.007.

Hanneke, Rosie, and Jeanne M. Link. 2019. "The Complex Nature of Research Dissemination Practices among 
Public Health Faculty Researchers.” Journal of the Medical Library Association 107 (3): 341-51. https://doi.org/10.5195/jmla.2019.524.

Lapolla, Fred Willie Zametkin, and Denis Rubin. 2018. “The 'Data Visualization Clinic': A Library-Led Critique Workshop for Data Visualization.” Journal of the Medical Library Association 106 (4): 47782. https://doi.org/10.5195/jmla.2018.333.

Naum, Alexandra. 2014. "Research Data Storage and Management: Library Staff Participation in Showcasing Research Data at the University of Adelaide." Australian Library Journal 63 (1): 35-44. https://doi.org/10.1080/00049670.2014.890019.

Payal, Shipra Awasthi, and Manorama Tripathi. 2019. "A Selective Review of Literature on Research Data Management in Academic Libraries." DESIDOC Journal of Library and Information Technology 39 (6): 338-45. https://doi.org/10.14429/djlit.39.06.14451.

Pinfield, Stephen, Andrew M. Cox, and Jen Smith. 2014. "Research Data Management and Libraries: Relationships, Activities, Drivers and Influences." PLoS ONE 9 (12): 1-28. https://doi.org/10.1371/journal.pone.0114734.

Rahayu, Nur. 2016. “Jurnal Pari PERANAN PUSTAKAWAN DALAM MENDUKUNG KNOWLEDGE MANAJEMEN REPOSITORY KEMENTERIAN KELAUTAN DAN PERIKANAN LIBRARIAN ROLE TO SUPPORT MANAGEMENT KNOWLEDGE REPOSITORY MINISTRY OF MARINE AFFAIRS AND FISHERIES ( MMAF ).” Jurnal Pari. Http://Ejournal-Balitbang.Kkp.Go.Id/ 2 (8): 4351.

Read, Kevin B., Jessica Koos, Rebekah S. Miller, Cathryn F. Miller, Gesina A. Phillips, Laurel Scheinfeld, and Alisa Surkis. 2019. “A Model for Initiating Research Data Management Services at Academic Libraries." Journal of the Medical Library Association 107 (3): 432-41. https://doi.org/10.5195/jmla.2019.545.

Riyanto, Slamet, Ekawati Marlina, and Hermin Triasih. 2019. "Librarian Role in Research Library Services in Indonesian Institute of Sciences.” Berkala Ilmu Perpustakaan Dan Informasi 15 (2): 201. https://doi.org/10.22146/bip.35200.

Shelly, Marita, and Margaret Jackson. 2018. "Research Data Management Compliance: Is There a Bigger Role for University Libraries?” Journal of the Australian Library and Information Association 67 (4): 394410. https://doi.org/10.1080/24750158.2018.1536690.

Shonhe, Liah. 2017. "A Literature Review of Information Dissemination Techniques in the 21st Century Era." Library Philosophy and Practice (e-Journal). http://digitalcommons.unl.edu/libphilprac/1731/.

Syarianah. 2016. "Jurnal Pari" 2 (129): 2-5.

Tenopir, Carol, Ben Birch, and Suzie Allard. 2012. "Academic Libraries and Data Services in Academic Libraries." College \& Research Libraries 46 (3): 61-75. http://www.ala.org/acrl/sites/ala.org.acrl/files/content/publications/whitepapers/Tenopir_Birch_Allard.p df.

Tenopir, Carol, Robert J. Sandusky, Suzie Allard, and Ben Birch. 2014. "Research Data Management Services in Academic Research Libraries and Perceptions of Librarians." Library and Information Science Research 36 (2): 84-90. https://doi.org/10.1016/j.lisr.2013.11.003.

Ulum, Amirul. 2011. "Pengelolaan Sistem Informasi Karya Ilmiah.” Pustakaloka 3 (1): 106-16. https://doi.org/10.21154/PUSTAKALOKA.V3I1.638.

Yoon, Ayoung, and Teresa Schultz. 2017. "Research Data Management Services in Academic Libraries in the US: A Content Analysis of Libraries’ Websites.” College and Research Libraries 78 (7): 920-33. https://doi.org/10.5860/crl.78.7.920. 